\title{
Egg production by the bay anchovy Anchoa mitchilli in relation to adult and larval prey fields
}

\author{
E. B. Peebles*, J. R. Hall, S. G. Tolley \\ Department of Marine Science, University of South Florida, 140 Seventh Avenue SE, St. Petersburg, Florida 33701, USA
}

\begin{abstract}
Abundances of copepod nauplii, copepodite/adult copepods, and the larvae of iteroparous anchovies (primarily the bay anchovy Anchoa mitchilli) were monitored in Tampa Bay, Florida (USA) at $2 \mathrm{wk}$ intervals for $2 \mathrm{yr}$. All possible pairings of the 3 time-series variables yielded significant positive correlations. Nearly all ( $>98 \%$ ) of the collected anchovy larvae occurred with prey (nauplius) densities higher than those reported to affect larval starvation $\left(<100 \mathrm{l}^{-1}\right)$. The larval association with abundant prey could be explained as (1) the remnants of earlier larval starvation, or (2) spawning being concentrated in zooplankton-rich waters. To evaluate the 2 explanations, the diet of adult $A$. mitchilli was analyzed, and egg/adult prey surveys were conducted across a $290 \mathrm{~km}^{2}$ area of Tampa Bay. In 5 of the 6 spatial surveys, A. mitchilli egg abundance was correlated with the abundance of calanoid copepods, a principal adult prey item. Calanoids (primarily adult Acartia tonsa) were never correlated with net plankton biomass or with the eggs of the bay anchovy's congener, Anchoa hepsetus. Calanoids were aggregated near sites of stable freshwater discharge during a dry season, but became dispersed as discharge increased during a rainy season. Among spatial surveys, egg abundance exhibited a strong nonlinear relationship with calanoid aggregation $\left(\mathrm{r}^{2}=0.96, \mathrm{n}=6, \mathrm{p}=0.001\right)$. Collectively, these findungs suggest that the bay anchovy's size-specific fecundity is related to adult prey avallability, with adult prey availability being represented by a combination of abundance and patchiness. We discuss relationshups between spawning pattern and environmental instability, and suggest that iteroparity serves to fine-tune reproductive effort to environmental parameters that are relevant to larval survival.
\end{abstract}

KEY WORDS: Variable fecundity - Larval survival Plankton patchiness Life-hıstory strategy Spawning season Spawning location

\section{INTRODUCTION}

The addition of recruits to adult fish populations is difficult to predict from parent stock size alone. Gulland (1983) stated '...the most obvious feature of the pattern of recruitment to most fish stocks is that it bears no obvious relation to the abundance (or other characteristic) of the parent stock.' Over the past several decades, substantial effort has been spent identifying the cause of variation in the relationship between stock and recruitment

Given that planktonic larvae are subject to starvation if they do nat find sufficient food within a 'critical period' after hatching (May 1974, Houde 1977, 1978), variation in larval prey availability is thought to con-

·E-mail:epeebles@ix.netcom.com tribute substantially to variation in the stock-recruitment relationship (Lasker 1985. Cushing 1990). Although it is often assumed that the initial reproductive effort (egg production) is proportionate to the size of the adult stock, several studies indicate that sizespecific fecundity may be significantly influenced by adult ration (Bagenal 1973, Bailey \& Almatar 1989, Tsuruta \& Hirose 1989). It is therefore possible that variable size-specific fecundity is a contributor to variation in the stock-recruitment relationship (Rothschild 1986).

We investigated this problem by examining the natural plankton distributions relevant to the variable larval starvation and variable fecundity processes. Our approach was interactive in the sense that the results of one plankton survey prompted the design of more specific surveys. The first survey (the temporal survey) sug- 
gested that planktonic anchovy larvae are consistently associated with abundant prey (copepod nauplii). Yet because the larvae collected during the temporal survey were generally older than first-feeding age, it was not clear if their association with abundant prey was caused by (1) spatially variable larval starvation during the critical period, or (2) the zooplanktivorous adults spawning more heavily in zooplankton-rich waters

To evaluate the 2 possibilities, we analyzed adult diet and conducted a second series of surveys (spatial surveys). The spatial surveys targeted the eggs and adult prey of the bay anchovy Anchoa mitchilli (family Engraulidae), but also generated egg data for the less abundant striped anchovy $A$. hepsetus. The bay anchovy is a small $(<110 \mathrm{~mm}$ ) forage fish that occurs in coastal waters from Maine (USA) to Yucatan (Mexico) and is abundant throughout much of this range (Jones et al. 1978, Luo \& Musick 1991). This species is shortlived, with some estimates indicating that $>90 \%$ of total egg production is contributed by age- 1 females (Zastrow et al. 1991). The bay anchovy can be highly iteroparous, spawning 50 to 60 times over several months (Luo \& Musick 1991, Zastrow et al. 1991). The principal. objective of the spatial surveys was to determine if the bay anchovy's egg production is correlated with adult prey availability. In some contexts, we refer to striped anchovy data for comparative purposes

\section{METHODS}

Temporal survey. Replicate oblique plankton net tows and replicate Niskin bottle casts were made at the location in Fig, 1 at $2 \mathrm{wk}$ intervals from January 1988 to January 1990 (48 collection dates). All collections were made at night on an incoming tide. Plankton net collections were made with a $0.5 \mathrm{~m}$ mouth diameter, $505 \mu \mathrm{m}$ mesh net equipped with a $9 \mathrm{~kg}$ mouth-ring weight and a digital flowmeter. The net was towed by an outboardpowered boat at approximately $1.7 \mathrm{~m} \mathrm{~s}^{-1}$ for $5 \mathrm{~min}$, filtering a mean volume of $75 \mathrm{~m}^{3}$ Tow duration was divided evenly between bottom, mid-depth, and surface. The catch was rinsed into the cod-end jar and preserved in 6 to $10 \%$ buffered formalin. Four casts with an 11 l Niskin bottle were made in association with each plankton net tow, with the 4 casts being distributed through the water column to simulate the water column coverage by the net. The 441 water sample was filtered through $28 \mu \mathrm{m}$ mesh, and the catch was rinsed into a sample jar containing buffered formalin.

In the laboratory, anchovy eggs and larvae were enumerated using a dissecting microscope. Some counts were based on samples that had been divided using a box-type sample splitter. Although the eggs of Anchod mitchilli are readily distinguished from those

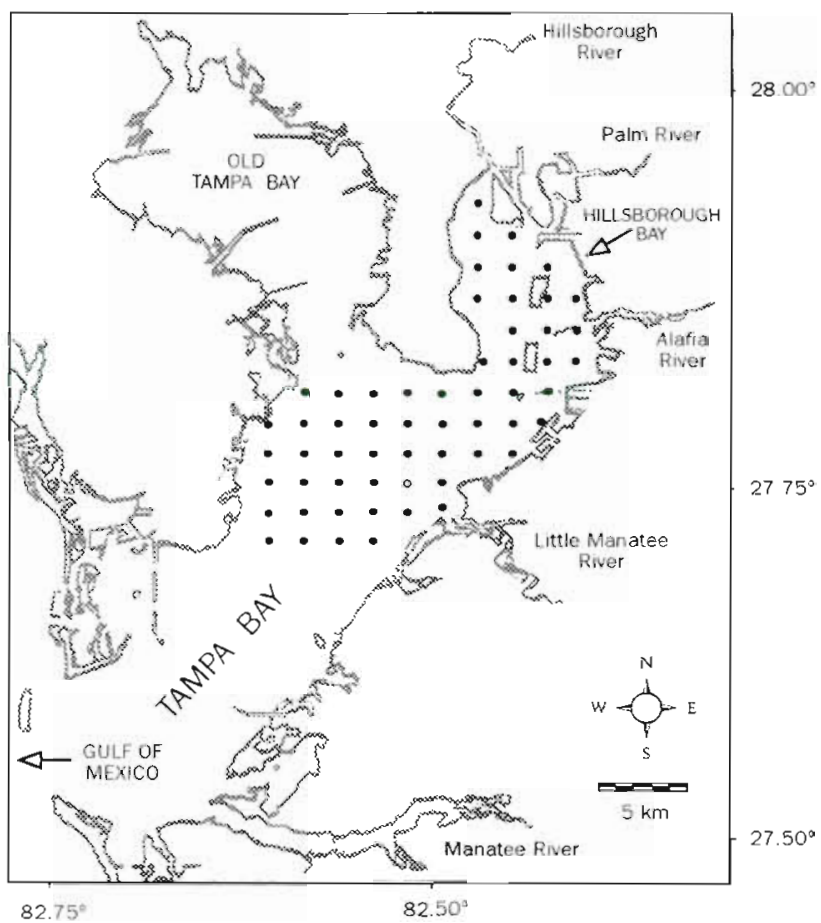

Fig. 1. Map of study area in Florida, USA, and station locations. Open circle is station sampled during temporal survey; all stations (open and solid circles) were sampled during spatial surveys

of A. hepsetus, the preflexion-stage larvae of the 2 species could not be consistently separated and were therefore grouped together as Anchoa spp. larvae. Copepod nauplii and copepodites/adults collected by the Niskin bottle were enumerated using the same procedure as used for anchovy eggs and larvae.

Diet survey. Diet information was used to identify the adult prey to be surveyed in subsequent spatial surveys. On 50 occasions during 1991 and 1992, seines and trawls were used to collect adult bay anchovies [30 to $53 \mathrm{~mm}$ standard length (SL), $\mathrm{n}=177$ ] from widely distributed locations in the Tampa Bay estuary. Usually fewer than 5 and never more than 10 anchovies were examined from each of the 50 collections. Items in the stomach were removed and distrubuted in glycerol on a microscope slide, covered with a cover slip, and scanned at 10 to $400 \times$ magnification. Item volumes were estimated from geometric models based on measurements of average dimensions made with an ocular micrometer

Spatial surveys. The egg and adult anchovy prey surveys were designed to investigate (1) spatial distribution of eggs and adult prey (comparisons among stations) and (2) spatial dynamics of eggs and adult prey (comparisons among surveys). A $290 \mathrm{~km}^{2}$ area of the Tampa Bay estuary (Fig. 1) was surveyed 6 times, with 
3 surveys conducted during a seasonally low freshwater discharge period (dry season; 'Dry 1', 'Dry 2' and 'Dry 3') and 3 conducted during a seasonally high freshwater discharge period (wet season; 'Wet 1', 'Wet 2 ' and 'Wet 3'j. Fifty-eight stations were selected within a region that included areas subject to strong influence by estuarine tributaries (eastern Tampa Bay) and areas with less riverine influence (western Tampa Bay).

Collection gear for the spatial surveys consisted of a $0.5 \mathrm{~m}$ mouth diameter, $333 \mu \mathrm{m}$ mesh plankton net equipped with a $5 \mathrm{~kg}$ mouth-ring weight and a digital flowmeter. The net was towed at the surface at approximately $1.0 \mathrm{~m} \mathrm{~s}^{-1}$ for $30 \mathrm{~s}$, filtering a mean volume of $9.1 \mathrm{~m}^{3}$. Upon retrieval, the net was washed from the outside using an electric wash-down pump. The catch was retained by a $333 \mu \mathrm{m}$ bucket filter and was then rinsed back into the original cod-end jar using 75 to $500 \mathrm{ml}$ of $50 \%$ isopropanol. Each of the 6 surveys consisted of a single collection at each of the 58 stations. Electronic meters were used to measure surface salinity and water temperature after each tow.

Because we were collecting at the surface and did not want wind mixing to influence apparent organism densities, we selected collection dates with a calm sea state. In order to keep time of collection as similar as possible among collections, we traveled at 60 to $85 \mathrm{~km}$ $\mathrm{h}^{-1}$ along the sampling route using a LORAN-based navigational plotter to locate stations. We sampled the upper and lower halves of the survey area on 2 consecutive days, except during the fourth survey, when bad weather on the second day of sampling forced us to add a third day to the survey period. The order in which the upper and lower halves of the survey area were sampled was determined by a coin toss. Within each half, the direction of the route (forward vs backward) was also determined by a coin toss. As a result, no two surveys had the same sampling sequence. Each survey was conducted between 09:30 and 16:30 h, with the mean time between consecutive collections being 8.3 min. Within surveys, the maximum difference in time of collection was $5.2 \mathrm{~h}$.

In the laboratory, Anchoa mitchilli and A. hepsetus eggs were enumerated using the procedure described above. Each cod-end jar was shaken to obtain a homogeneous distribution of copepods, and a $1 \mathrm{ml}$ aliquot was then withdrawn with a pipette pump. The copepods in the aliquot were enumerated using a dissecting microscope. The total number of copepods was estimated after the volumes of the cod-end jars' contents were measured in a graduated cylinder Error associated with this subsampling procedure was estimated by repeating the process 5 times for each of 10 randomly selected cod-end jars. This test yielded a mean coefficient of variation of $21 \%$. Net plankton bio- mass was estimated by volume displacement (Smith \& Richardson 1977).

Analyses of spatial distribution consisted of mapping Anchoa mitchilli egg and calanoid density distributions and correlating egg density, calanoid density, and net plankton biomass using Spearman's rank correlation. Spatial dynamics were investigated after first testing for significant variation in egg and calanoid densities among surveys using the Kruskal-Wallis 1-way analysis by ranks. Individual variables considered to be potentially operational in explaining among-survey variation in $A$. mitchilliegg abundance were evaluated using linear and nonlinear regressions. The potentially operational variables examined were moon phase, water temperature, salinity, freshwater discharge, calanoid abundance, and calanoid aggregation. The intent was to identify variables that may individually explain (or not explain) variation in egg abundance among the surveys. Many potentially operational variables, such as moon phase, freshwater discharge, and indices that represent organism aggregation, can only be expressed as a single observation for each survey. Therefore, the egg and calanoid abundances in each survey were also represented by single observations, specifically total catch-per-unit-effort (CPUE: total number collected/total volume filtered from 58 locations). Aggregation during a given survey was represented by David \& Moore's (1954) index of clumping $(I C)$

$$
I C=\frac{s^{2}}{\bar{x}}-1
$$

where $\bar{X}$ is the density and $s^{2}$ is the variance of the densities observed at 58 locations. Because the variance-tomean ratios of random distributions approach unity. subtraction of 1 produces index values that approach zero for random distributions and become increasingly positive with increased clumping. Salinity and water temperature during the surveys were represented as means of the 58 locations. Freshwater discharge into the study area was represented by summing the means of previous $10 \mathrm{~d}$ gauged flow for the 4 principal estuarine tributaries in the study area.

To determine if Anchoa mitchilli eggs and calanoids shifted their geographic location in association with isohaline shifts, the mean latitude and mean salinity of concentration for the 2 organisms were calculated as density-weighted means (WM) for each of the $j$ surveys:

$$
W M_{1}=\frac{\sum_{i} x_{i} d_{i}}{\overline{\sum_{i} d_{i}}}
$$

where $x$ is either latitude or salinity at station $i$ and $d$ is organism density. The respective weighted means for the 2 organisms were then correlated. 


\section{RESULTS}

\section{Temporal survey}

Over the 2 yr period. Anchoa mitchilli eggs outnumbered $A$. hepsetus eggs by a ratio of more than 17:1, which suggests that most of the preflexionstage anchovy larvae were $A$. mitchilli. The larval densities in Figs. 2 \& 3 were estimated from $505 \mu \mathrm{m}$ mesh plankton tows, and are probably large underestimates due to extrusion. More than $98 \%$ of the larvae (mean notochord length of $4.1 \mathrm{~mm}$ ) were associated with nauplius densities higher than $100 \mathrm{l}^{-1}$ $\left(=100000 \mathrm{~m}^{-3}\right.$ in Fig. 3). Estimated larval densities were strongly correlated with water temperature (Table 1) and dropped to zero during all 3 winters. Copepod nauplius and copepodite/adult densities were correlated, and each was correlated with water temperature. Nauplius densities fell below $100 \mathrm{l}^{-1}$ during the winters of 1987-88 and 1989-90, but remained above $100 \mathrm{l}^{-1}$ during the warmer winter of 1988-89 (Fig, 2).

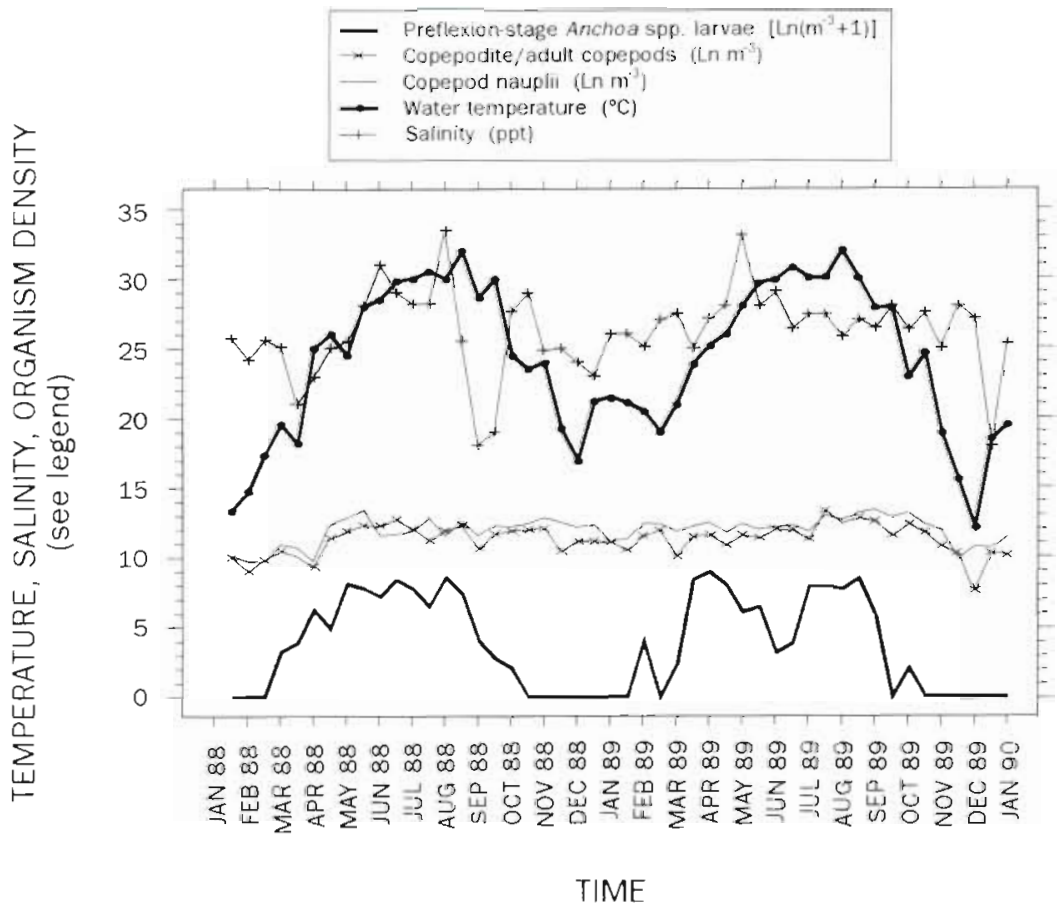

Fig. 2. Time-series variables. Each density estimate is mean of 2 replicate water column samples (see also Fig. 3)

\section{Adult diet and its relationship to survey data}

Approximately 20000 ingested items were identified from 172 stomachs (5 stomachs were empty) The data in Table 2 indicate that calanoid copepods, meroplankters (cirriped, decapod and pelecypod larvae), and epibenthic crustaceans (harpacticoid copepods, gammarid amphipods) were the dominant prey of adult bay anchovies in Tampa Bay. In both bay anchovy stomachs and the $333 \mu \mathrm{m}$ spatial survey samples, the calanoid copepod Acartia tonsa numerically dominated other copepod species by at least 1 order of magnitude. The calanoids in the stomach samples had a mean prosome length of $701 \mu \mathrm{m}$ (mean of 360 measurements from 72 stomachs), while those retained by the $333 \mu \mathrm{m}$ mesh had a mean prosome length of $951 \mu \mathrm{m}$ (mean of 400 measurements from 20 plankton collections).

Table 1. Correlated tume-series varables, ranked by product-moment correlation coefficient. $n=48$ for all correlations

\begin{tabular}{|c|c|c|c|}
\hline Variable 1 & Variabie 2 & $\mathrm{r}$ & $\mathrm{p}$ \\
\hline Copepod nauplii $\left[\ln \left(m^{-3}+1\right)\right]$ & All copepodite/adult copepods $\left[\ln \left(\mathrm{m}^{-3}+1\right)\right]$ & 0.77 & $<0.001$ \\
\hline All copepodite/adult copepods $\left[\ln \left(\mathrm{m}^{-3}+1\right)\right]$ & Copepodite/adult Acartia tonsa $\left[\ln \left(\mathrm{m}^{-3}+1\right)\right]$ & 0.74 & $<0.001$ \\
\hline All copepodite/adult copepods $\left[\ln \left(\mathrm{m}^{-3}+1\right)\right]$ & Water temperature $\left({ }^{\circ} \mathrm{C}\right)$ & 0.74 & $<0.001$ \\
\hline Preflexion Anchoa spp. larvae $\left[\ln \left(\mathrm{m}^{-3}+1\right)\right]$ & Water temperature $\left({ }^{\circ} \mathrm{C}\right)$ & 0.72 & $<0.001$ \\
\hline Copepod nauplii $\left[\ln \left(\mathrm{m}^{-3}+1\right)\right]$ & Water temperature $\left({ }^{\circ} \mathrm{C}\right)$ & 0.59 & $<0.001$ \\
\hline Copepodite/adult Acartia tonsa $\left[\ln \left(\mathrm{m}^{-3}+1\right)\right]$ & Water temperature $\left({ }^{\circ} \mathrm{C}\right)$ & 0.56 & $<0.001$ \\
\hline Copepodite/adult Acartia tonsa $\left[\ln \left(\mathrm{m}^{-3}+1\right)\right]$ & Copepod nauplii $\left[\ln \left(m^{-3}+1\right)\right]$ & 0.49 & $<0.001$ \\
\hline Preflexion Anchoa spp. larvae $\left[\ln \left(\mathrm{m}^{-3}+1\right)\right]$ & Copepodite/adult Acartia tonsa $\left[\ln \left(\mathrm{m}^{-3}+1\right)\right]$ & 0.38 & 0.008 \\
\hline Preflexion Anchoa spp. larvae $\left[\ln \left(\mathrm{m}^{-3}+1\right)\right]$ & Copepod nauplii $\left[\ln \left(m^{-3}+1\right)\right]$ & 0.34 & 0017 \\
\hline All copepodite/adult copepods $\left[\ln \left(\mathrm{m}^{-3}+1\right)\right]$ & Salinity (ppt) & 0.33 & 0.021 \\
\hline Preflexion Anchoa spp. larvae $\left[\ln \left(\mathrm{mi}^{-3}+1\right)\right]$ & Salinity (ppt) & 0.31 & 0.029 \\
\hline Water temperature $\left(\mathrm{C}^{\circ}\right.$ & Salinity (ppt) & 0.29 & 0044 \\
\hline
\end{tabular}




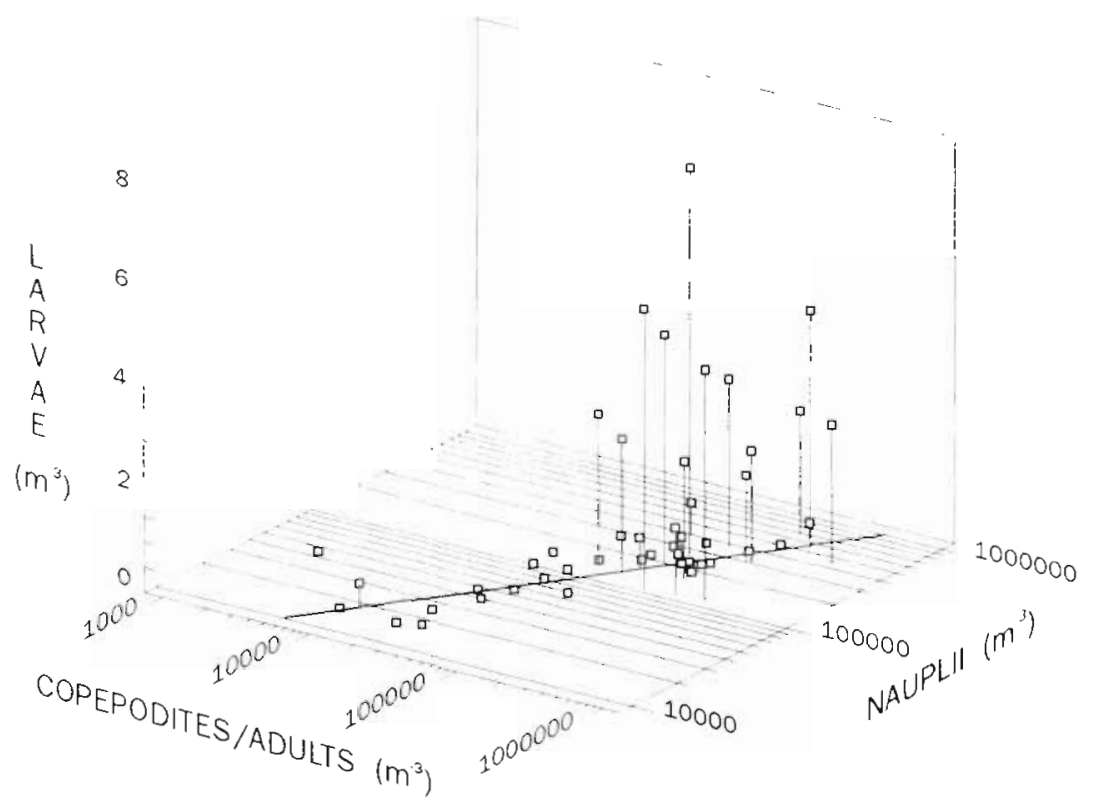

Fig. 3. Comparison of densities of preflexion-stage Anchoa spp. larvae, copepodite/adult copepods, and copepod nauplii from temporal survey (same data as in Fig. 2). Each density estimate is mean of 2 replicate water column samples. The regression between $1 n$-transformed copepod and nauplius densities (diagonal line $)$ s: $\left[\right.$ nauplii] $=63.98+1.99\left[\right.$ copepods] $\left(r^{2}=0.59, n=48, p<0.0001\right)$ survey and when data from all surveys were combined.

\section{Spatial dynamics of Anchoa mitchilli eggs and calanoid copepods}

Descriptive statistics for the spatial surveys are presented in Table 4. Anchoa mitchilli eggs were essentially absent from the southwestern portion of the survey area during the dry season surveys and from much of Hillsborough Bay during the wet season surveys (Fig. 4). The latitudes and salinities of concentration (densityweighted means) for calanoids and $A$. mitchilli eggs were strongly correlated (Table 5). Both organisms moved toward the Gulf of Mexico during the wet season, and remained consistently associated with salinities of 26 to 28 ppt (Tables 4 \& 5). David \& Moore's (1954) test indicates that mean clumping was significantly higher during the dry season for both calanoids ( $w=$ $-0.86, p<0.05)$ and $A$. mitchilli eggs $(w=-0.59, p<0.05)$.

\section{Spatial distribution of Anchoa mitchilli eggs and calanoid copepods}

Areas of high Anchoa mitchilli egg density tended to coincide with areas of high calanoid density (Fig. 4). The density scales in Fig 4 change from survey to survey in order to increase resolution of patchiness. Observations of instantaneous densities from all surveys are plotted together in Fig. 5, where it is evident that high $A$. mitchilli egg densities only occurred where calanoid densities were also high. In contrast, high calanoid densities were observed in the absence of high A. mitchilli egg densities (Fig. 5). Five of the 6 surveys contributed observations of $>500$ eggs $\mathrm{m}^{-3}$ to Fig. 5. Positive correlations between instantaneous $A$. mitchilli egg and calanoid densities were highly significant in 5 of the 6 surveys and when all data were combined (Table 3). A. mitchilli egg densities were correlated with net plankton biomass during 2 surveys, but not when data from all surveys were combined. Calanoid densities appeared to be independent of net plankton biomass during all surveys. A. hepsetus egg density was not correlated with calanoid density during any of the surveys, but was correlated with net plankton biomass during 4 surveys and when data from all surveys were combined. Densities of $A$. hepsetus and $A$. mitchilli eggs were weakly correlated in 1
Anchoa mitchilli egg and calanoid densities varied significantly among surveys (Kruskal-Wallis test, p <

Table 2 . Items constituting $\geq 1 \%$ of stomach content volume of adult Anchoa mitchilli ( 30 to $53 \mathrm{~mm} \mathrm{SL}$ ) from the Tampa Bay estuary

\begin{tabular}{|lrcc|}
\hline Diet category & $\begin{array}{c}\text { Volume } \\
(\%)\end{array}$ & $\begin{array}{c}\text { Occurrence } \\
(\%)\end{array}$ & $\begin{array}{c}\text { Importance } \\
(\mathrm{V} \times \mathrm{O} / 10)\end{array}$ \\
\hline Calanoid copepods & 16 & 48 & 76.8 \\
Cirrped cypris larvae & 6 & 45 & 27.0 \\
Harpacticoid copepods & 5 & 51 & 25.5 \\
Gammarid amphipods & 22 & 10 & 22.0 \\
Decapod mysis larvae & 12 & 9 & 11.8 \\
Pelecypod larvae & 2 & 53 & 10.6 \\
Decapod zoeae & 2 & 15 & 3.0 \\
Crustacean parts & 2 & 15 & 3.0 \\
Cumaceans & 4 & 5 & 2.0 \\
Ostracods & 1 & 19 & 1.9 \\
Sand grains & 1 & 16 & 1.6 \\
Mysids & 7 & 2 & 1.4 \\
Polychaetes & 3 & 4 & 1.2 \\
lnvertebrate eggs & 1 & 8 & 0.8 \\
Amorphous detritus & 2 & 3 & 0.6 \\
Amphipod parts & 1 & 5 & 0.5 \\
Fish remains & 4 & 1 & 0.4 \\
Isopods & 2 & 2 & 0.4 \\
Decapod megalopae & 1 & 3 & 0.3 \\
Caprellid amphipods & 1 & 1 & 0.1 \\
& & & \\
\hline
\end{tabular}



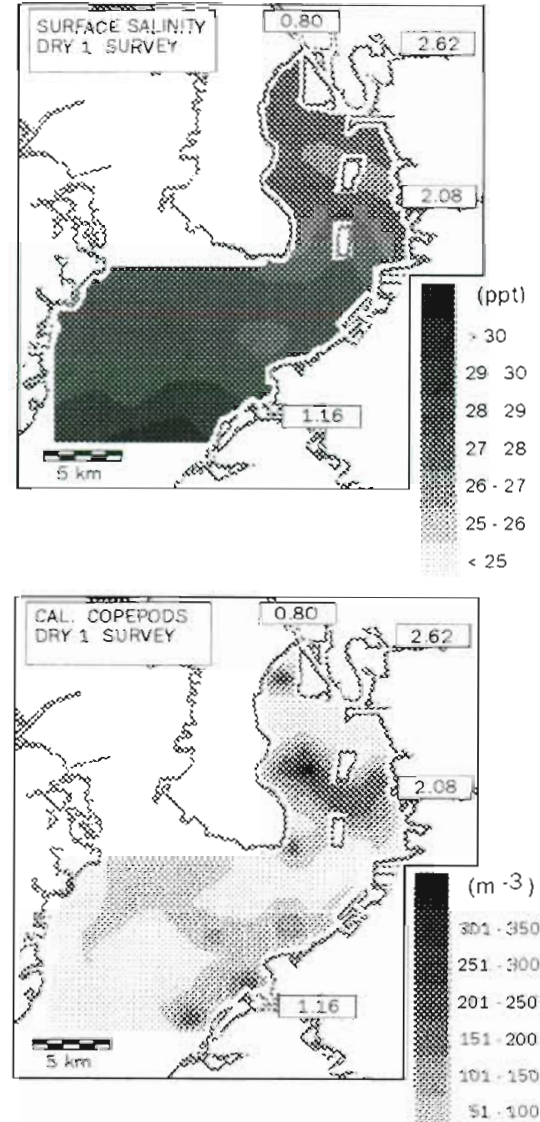

1. 50

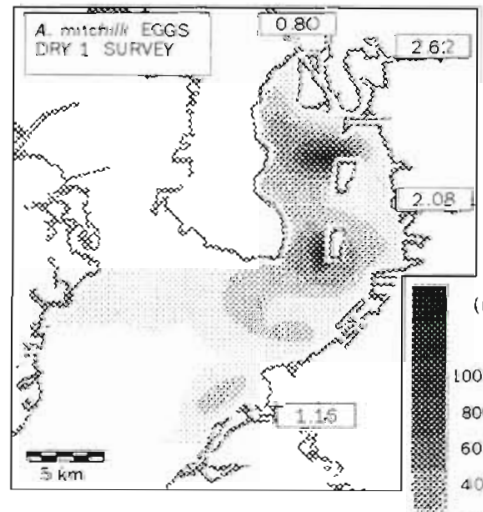

$(m-3)$

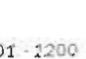

$801-1000$

601.800

$401 \cdot 600$

$201-400$
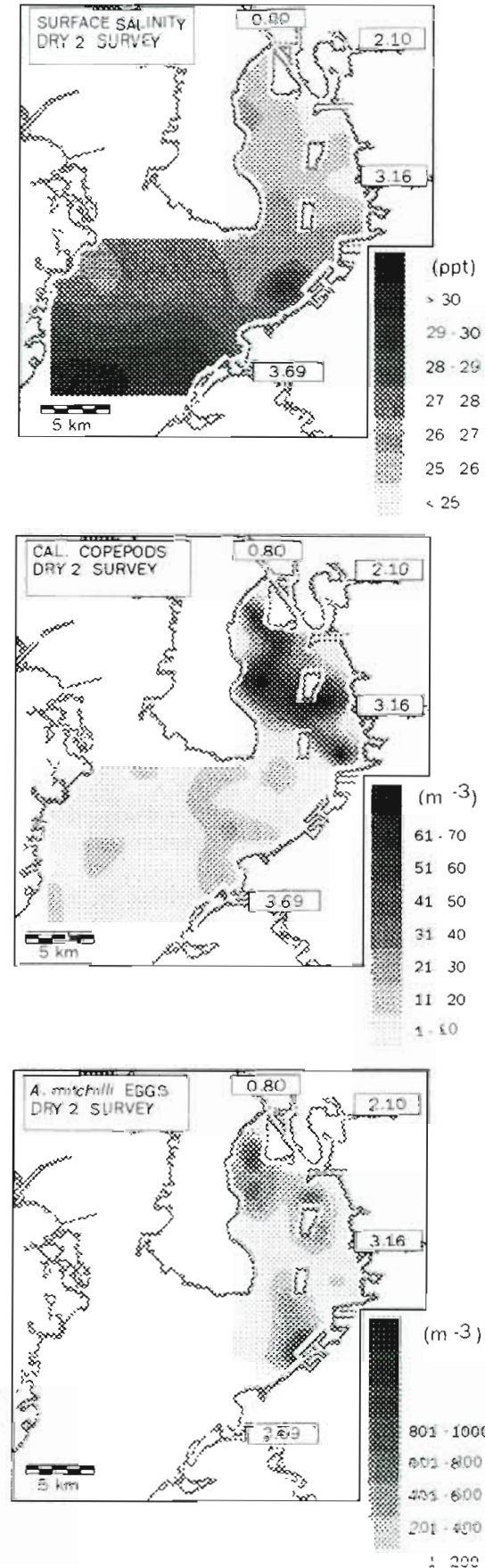
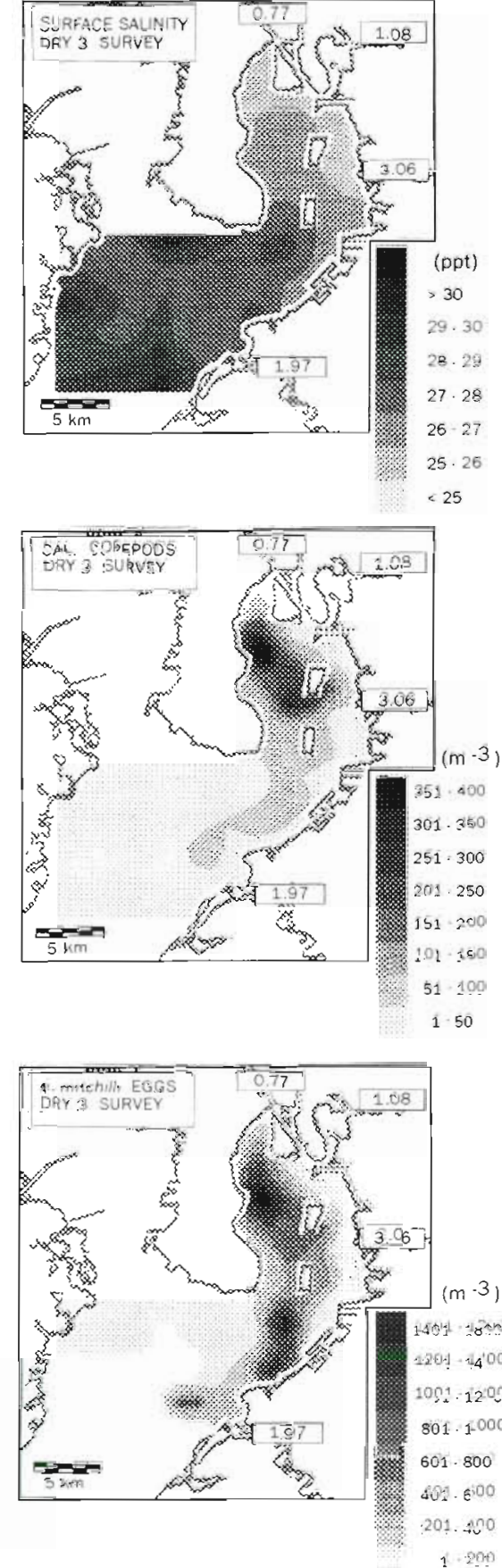

Fig 4 Maps of surface salınity, calanoid density, and Anchoa mitchill egg density, arranged in columns by survey. Small boxes indicate mean gauged freshwater discharge $\left(\mathrm{m}^{3} \mathrm{~s}^{-1}\right)$ durnng previous $10 \mathrm{~d}$

0.001). Survey egg CPUE was correlated with survey calanoid CPUE (Table 5). Nonlınear models did not improve the fit of this relationship. A much stronger, nonlinear relationship appeared to exist between survey egg CPUE and the index of clumping $(\mathrm{IC})$ for calanoids ( Flg 6).

\section{DISCUSSION}

Survival of Anchoa mitchilli larvae is reported to be consistently high when the larvae are maintained at nauplius concentrations $>100 \mathrm{l}^{-1}$ (Houde 1977, 1978). During the 2 yr monitoring of Tampa Bay, the abundances of 

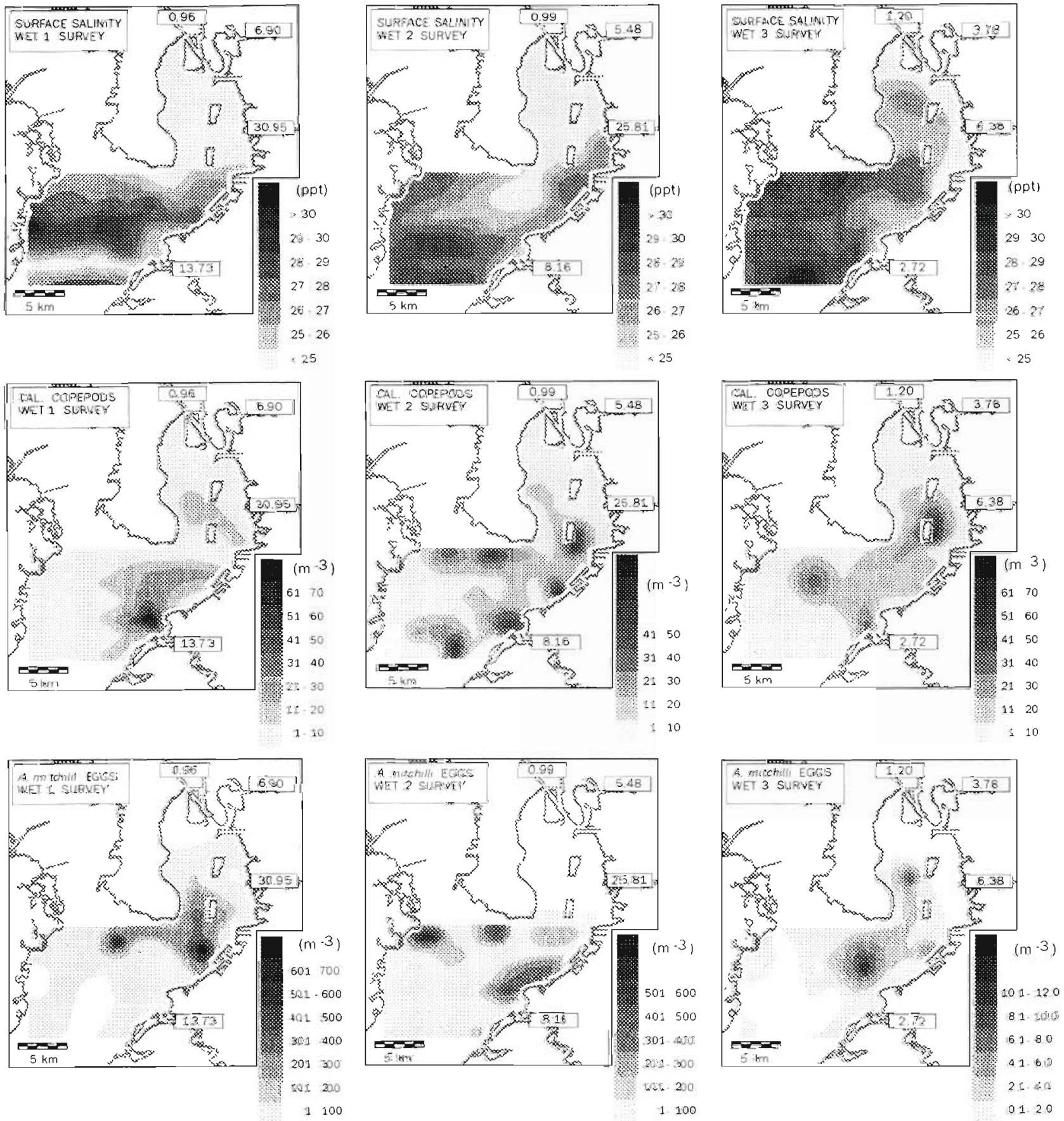

Fig 4 (continued)

preflexion-stage larvae and nauplii were correlated to the extent that nearly all larvae $(98.8 \%)$ were associated with nauplius concentrations $>100 \mathrm{l}^{-1}$ (= $100000 \mathrm{~m}^{-3} \mathrm{in}$ Fig. 3). In a similar 2 yr survey of Great South Bay, New York (USA), Castro \& Cowen (1991) also found a correlation between $A$. mitchill larvae and copepod nauplius concentrations. There is no current consensus on the processes responsible for these associations.
One explanation is that the adults spawn in direct response to temperature and photoperiod, as suggested by Zastrow et al. (1991) and Castro \& Cowen (1991), and that the association between older larvae and their prey occurs as the result of spatio-temporal variability in survival of first-feeding larvae. An alternative explanation is that the eggs are spawned in zooplankton-rich waters. Because the $505 \mu \mathrm{m}$ mesh used 
Table 3. Spearman's rank correlations between plankton constituents. 'Significant correlation

\begin{tabular}{|c|c|c|c|}
\hline Survey & $\mathrm{n}$ & $r$ & $\mathrm{p}$ \\
\hline \multicolumn{4}{|c|}{ Anchoa mitchilli eggs and calanoid copepods } \\
\hline Dry 1 & 58 & 0.20 & 0.13 \\
\hline Dry 2 & 58 & $0.41^{\circ}$ & 0.002 \\
\hline Dry 3 & 58 & $0.77^{\circ}$ & $<0.001$ \\
\hline Wet 1 & 58 & $0.53^{\circ}$ & 0.001 \\
\hline Wet 2 & 58 & $0.53^{\circ}$ & 0.001 \\
\hline Wet 3 & 58 & $0.50^{\circ}$ & $<0.001$ \\
\hline All survers & 348 & $0.47^{\circ}$ & $<0.001$ \\
\hline \multicolumn{4}{|c|}{ Anchoa mitchilli eggs and net plankton biomass } \\
\hline Dry 1 & 58 & -0.05 & 0.72 \\
\hline Dry 2 & 58 & $0.26^{*}$ & 0.05 \\
\hline Dry 3 & 58 & 0.21 & 0.12 \\
\hline Wet 1 & 58 & -0.04 & 0.76 \\
\hline Wet 2 & 58 & $0.61^{\bullet}$ & $<0.001$ \\
\hline Wet 3 & 58 & -0.02 & 0.99 \\
\hline All surveys & 348 & 0.03 & 0.57 \\
\hline \multicolumn{4}{|c|}{ Calanoid copepods and net plankton biomass } \\
\hline Dry 1 & 58 & 0.22 & 0.10 \\
\hline Dry 2 & 58 & -0.03 & 0.84 \\
\hline Dry 3 & 58 & 0.17 & 0.19 \\
\hline Wet 1 & 58 & -0.13 & 0.34 \\
\hline Wet 2 & 58 & 0.23 & 0.08 \\
\hline Wet 3 & 58 & -0.09 & 0.49 \\
\hline All surveys & 348 & -0.02 & 0.67 \\
\hline \multicolumn{4}{|c|}{ Anchoa hepsetus eggs and calanoid copepods } \\
\hline Dry 1 & 58 & -0.14 & 0.27 \\
\hline Dry 2 & 58 & 0.02 & 0.85 \\
\hline Dry 3 & 58 & -0.24 & 0.07 \\
\hline Wet 1. & 58 & 0.01 & 0.97 \\
\hline Wet 2 & 58 & 0.24 & 0.07 \\
\hline Wet 3 & 58 & 0.14 & 0.29 \\
\hline All surveys & 348 & 0.03 & 0.61 \\
\hline \multicolumn{4}{|c|}{ Anchoa hepsetus eggs and net plankton biomass } \\
\hline Dry 1 & 58 & $0.35^{\circ}$ & 0.009 \\
\hline Dry 2 & 58 & $0.30^{*}$ & 0.025 \\
\hline Dry 3 & 58 & -0.04 & 0.78 \\
\hline Wet 1 & 58 & $0.61^{\circ}$ & $<0.001$ \\
\hline Wet 2 & 58 & $0.49^{\circ}$ & 0.002 \\
\hline Wet 3 & 58 & 0.08 & 0.53 \\
\hline All surveys & 348 & $0.23^{\circ}$ & $<0.001$ \\
\hline \multicolumn{4}{|c|}{ Anchoa hepsetus eggs and Anchoa mitchilli eggs } \\
\hline Dry 1 & 58 & 0.01 & 0.93 \\
\hline Dry 2 & 58 & 0.15 & 0.25 \\
\hline Dry 3 & 58 & -0.13 & 0.32 \\
\hline Wet 1 & 58 & 0.09 & 0.50 \\
\hline Wet 2 & 58 & $0.29^{\circ}$ & 0.028 \\
\hline Wet 3 & 58 & 0.19 & 0.15 \\
\hline All surveys & 348 & $0.16^{\circ}$ & 0.004 \\
\hline
\end{tabular}

in our temporal survey primarily retained older preflexion larvae, the temporal data cannot be used to evaluate these 2 potential explanations.

Anchod mitchilli consumes copepods throughout its life, undergoing ontogenetic progress through various stages and sizes of copepods (Hunter 1981,

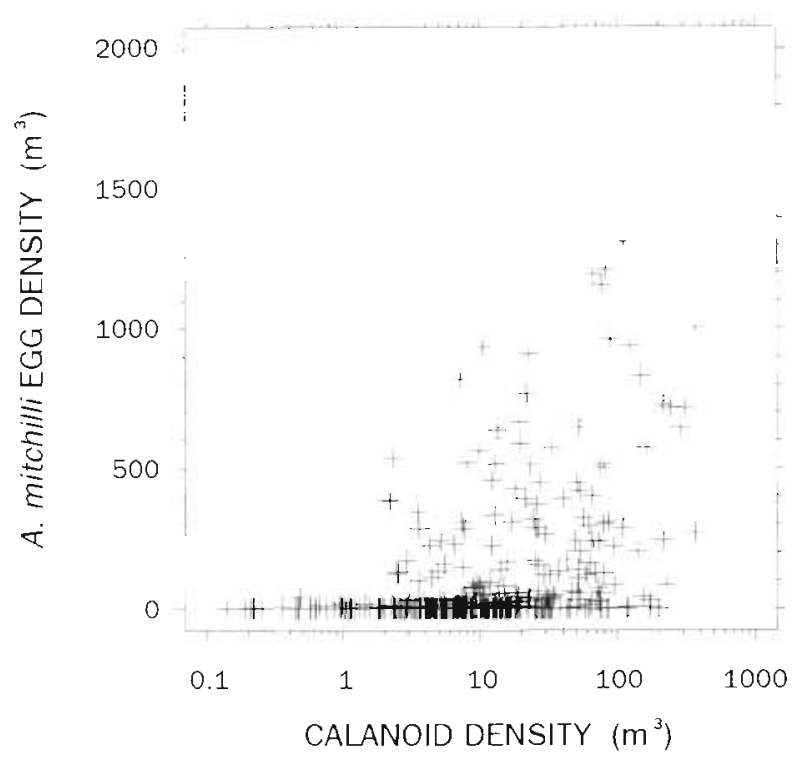

Fig. 5. Comparison of instantaneous Anchoa mitchilliegg and calanoid densities, all spatial surveys combined

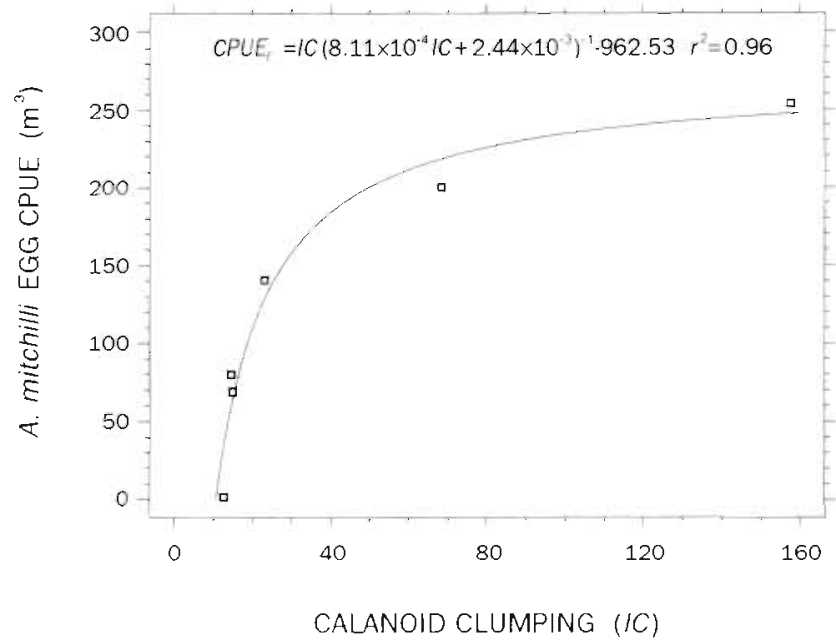

Fig. 6. Variation in Anchoa mitchilli egg catch-per-unit-effort (CPUE) with calanoid clumping. Each observation is calculated from 58 samples

Houde \& Lovdal 1984). Approximately half of the adult anchovy stomachs examined contained adult calanoid copepods (Table 2). Gammarid amphipods and decapod mysis larvae occurred at a much lower frequency, and tended to occur in advanced states of digestion. Hyslop (1980) noted that large items may be retained in the stomach longer than small items, causing overestimation of the importance of the large items in the diet. This appeared to be the case for the comparably large gammarids and mysis larvae found in the stomachs, and we would therefore characterize the adult bay anchovy as a calanoid feeder 
Table 4. Spatıal survey characteristics. Each mean and variance is calculated from 58 collections. Weighted means (WM) are weighted by organism densities at collection. Gauged freshwater (FW) discharge is the mean discharge into survey area over $10 \mathrm{~d}$ period prior to first day of each survey

\begin{tabular}{|c|c|c|c|c|c|c|}
\hline & Dry 1 & Dry 2 & Dry 3 & Wet 1 & Wet 2 & Wet 3 \\
\hline Survey date (1993) & 28-29 May & $3-4$ Jun & $9-10 \mathrm{Jun}$ & 13-15 Sep & $21-22$ Sep & $11-12 \mathrm{Oct}$ \\
\hline Moon phase $(1.0=$ full $)$ & 0.5 & 1.0 & 0.6 & 0.0 & 0.5 & 0.3 \\
\hline Tide at spawning & Ehb & Flood & Flood & Flood & Flood & Flood \\
\hline Gauged FW discharge $\left(\mathrm{m}^{3} \mathrm{~s}^{-1}\right)$ & 6.7 & 6.9 & 6.9 & 52.5 & 40.4 & 14.1 \\
\hline Egg CPUE $\left(\mathrm{m}^{3}\right)$ & 199.9 & 140.9 & 253.6 & 79.5 & 68.5 & 1.3 \\
\hline Egg density mean $\left(\mathrm{m}^{-3}\right)$ & 174.0 & 141.4 & 243.0 & 78.1 & 71.3 & 1.2 \\
\hline Egg density variance $\left(\mathrm{m}^{-3}\right)$ & 76201.2 & 76968.3 & 149862.2 & 20419.5 & 16421.0 & 4.5 \\
\hline Calanoid CPUE $\left(\mathrm{m}^{-3}\right)$ & 69.0 & 16.8 & 60.5 & 8.8 & 14.9 & 11.9 \\
\hline Calanord density mean $\left(\mathrm{m}^{-3}\right)$ & 67.3 & 17.0 & 57.7 & 8.5 & 15.0 & 11.3 \\
\hline Calanoid density variance $\left(\mathrm{m}^{-3}\right)$ & 4658.7 & 408.5 & 9152.8 & 132.2 & 235.6 & 153.0 \\
\hline Mean collection salinity (ppt) & 28.4 & 27.5 & 27.6 & 25.6 & 26.1 & 27.3 \\
\hline Calanoid WM salinity (ppt) & 28.1 & 26.6 & 26.6 & 26.2 & 26.8 & 27.3 \\
\hline Egg WM salinity (ppt) & 27.6 & 26.5 & 26.9 & 25.7 & 27.2 & 26.9 \\
\hline Mean collection water temp $\left({ }^{\circ} \mathrm{C}\right)$ & 27.0 & 29.8 & 31.3 & 30.6 & 31.6 & 27.9 \\
\hline Calanoid WM water temp. $\left(1^{\circ} \mathrm{C}\right)$ & 26.9 & 30.5 & 31.3 & 30.4 & 31.2 & 27.8 \\
\hline Egg WM water temp. $\left({ }^{\circ} \mathrm{C}\right)$ & 26.8 & 30.4 & 31.4 & 31.1 & 31.1 & 27.8 \\
\hline Mean collection latitude (constant) (') & 47.6 & 47.6 & 47.6 & 47.6 & 47.6 & 47.6 \\
\hline Calanoid WM latitude (') & 48.5 & 50.2 & 50.8 & 46.9 & 46.8 & 47.9 \\
\hline Egg WM latitude (') & 50.3 & 50.9 & 50.0 & 47.9 & 46.8 & 47.5 \\
\hline Calanoid clumping $(I C)$ & 68.2 & 23.0 & 157.6 & 14.6 & 14.7 & 12.5 \\
\hline Egg clumping $(I C)$ & 436.9 & 543.3 & 615.7 & 260.5 & 229.3 & 2.8 \\
\hline
\end{tabular}

Table 5. Linear regressions between potentıally operational variables in Table $4 . \mathrm{n}=6$ for all regressions. $\cdot$ Significant correlation

\begin{tabular}{|c|c|c|c|}
\hline Dependent variable & Independent variable & $r^{2}$ & Slope p \\
\hline Egg CPUE $\left(\mathrm{m}^{-3}\right)$ & Calanoid clumping $(I C)$ & $0.75^{\circ}$ & 0.027 \\
\hline Egg CPUE $\left(\mathrm{m}^{-3}\right)$ & Calanoid CPUE $\left(\mathrm{m}^{-3}\right)$ & $0.73^{\circ}$ & 0.030 \\
\hline Egg CPUE $\left(\mathrm{m}^{-3}\right)$ & Mean collection salinity (ppt) & 0.31 & 0.25 \\
\hline Egg CPUE $\left(\mathrm{m}^{-3}\right)$ & Gauged FW discharge $\left(\mathrm{m}^{3} \mathrm{~s}^{-1}\right)$ & 0.26 & 0.30 \\
\hline Egg CPUE $\left(\mathrm{m}^{-3}\right)$ & Moon phase & 0.20 & 0.38 \\
\hline Egg CPUE $\left(\mathrm{m}^{-3}\right)$ & Mean collection water temp. $\left({ }^{\circ} \mathrm{C}\right)$ & 0.01 & 0.86 \\
\hline Egg WM salinity (ppt) & Calanoid WM salinity (ppt) & $0.67^{\circ}$ & 0.048 \\
\hline Egg WM latitude (') & Calanoid WM latitude (') & $0.71^{\bullet}$ & 0.038 \\
\hline
\end{tabular}

that opportunistically exploits meroplankton and epibenthos.

Knowing that calanoids are important prey for adult Anchoa mitchilli in Tampa Bay, the spatial surveys were implemented to determine if $A$. mitchilli eggs are spatially correlated with calanoid abundance. By focusing on the egg stage, the effects of variable larval starvation were avoided. Egg sampling was limited to the top $0.5 \mathrm{~m}$ because $A$. mitchilli eggs have been reported to be buoyant (Jones et al. 1978). When sampling effort is distributed equally throughout the water column, the average sampling depth increases with the depth of the water column. If the eggs are buoyant, and if depth varies within the survey area, then an inconsistent sampling depth would bias the abundance estimates. Depth. was variable in our survey area, so we avoided this potential bias by collecting only at the surface on calm days. The $333 \mu \mathrm{m}$ mesh should have retained nearly all of the $A$. mitchilli eggs, which have a minimum diameter of approximately $650 \mu \mathrm{m}$ (Jones et al. 1978). The $333 \mu \mathrm{m}$ mesh retained calanoids that had a larger average size than those found in the adult A. mitchilli stomachs (951 vs $701 \mu \mathrm{m}$ prosome length). This bias was accepted because trial efforts using finer meshes resulted in more extensive net clogging.

Anchoa mitchilli egg densities were correlated with calanoid densities in 5 of the 6 spatial surveys and when all spatial survey data were combined, but were only correlated with net plankton biomass during 2 spatial surveys (Table 3). A. hepsetus egg densities 
exhibited the opposite trend, being correlated with net plankton biomass instead of calanoids. Calanoids were never correlated with net plankton biomass, which tended to be dominated by decapod zoeae and the decapod Lucifer faxoni. A. hepsetus grows to a larger size than $A$. mitchilli, and evidently discontinues feeding on copepods during a subadult dietary shift toward larger prey (Modde \& Ross 1983). Widespread independence among the plankton constituents in Table 3 indicates that the distributions cannot be entirely attributed to physical processes.

The spatial correlation illustrated by Fig. 5 appears to result from dependence of egg abundance on calanoid abundance, which contrasts sharply with the calanoids' apparent lack of dependence on egg density. The observations in the lower right corner of Fig. 5 indicate that there were many cases where high calanoid abundances were not accompanied by high egg abundances. The egg-calanoid correlations could have resulted because size-specific fecundity was higher where adult ration was higher, or because more fixed-fecundity adults were present in calanoid patches. In either case, the data indicate that associations between Anchoa mitchilli larvae and their prey can originate during the egg stage, and that variable larval starvation is not required to explain the associations between larvae and abundant prey.

The instantaneous observations in Fig. 5, however, may not adequately represent the prey 'field' encountered by the adult anchovies. Rothschild et al. (1989) asserted that representation of natural prey fields is improved by simultaneously considering the variance and mean of the prey distribution. Together, the variance and mean can be used to make inferences about the patchiness of the prey distribution. Without a concurrent measure of variability, mean or instantaneous measurements (such as those in Fig. 5) limit interpretation to the assumption that predation is adventitious across a random prey distribution. Variance-to-mean ratios increase naturally as the means of clumped distributions increase (Pielou 1977). David \& Moore's (1954) index (IC) therefore reflects a combination of abundance and patchiness. In this respect, $I C$ differs from the commonly used Lloyd's index of patchiness (Lloyd 1967), which was designed to isolate patchiness from abundance. Two surveys may produce identical Lloyd's index values despite strong dissimilarity in abundance, which is an attribute we considered undesirable for representing prey fields.

The question of whether size-specific fecundity is variable can be considered by examining the spatial dynamics of egg production. If size-specific fecundity is fixed over the short term, then adult biomass would have been required to nearly double during the $6 \mathrm{~d}$ between the Dry 2 and Dry 3 surveys in order to account for the near doubling of egg CPUE (Table 4). Adult migration into and out of the study area could bring about such changes, but would require another mechanism to maintain the balance (Fig. 6) outside the study area. In general, explaining Fig. 6 in terms of adult biomass fluctuation would require a high degree of coordination between predator and prey biomass distributions. On the other hand, Luo \& Musick (1991) discovered substantial short-term variation in the bay anchovy's interspawning interval, and suggested variation in daily ration as the cause. The variation in relative daily fecundity (mean no. eggs $\mathrm{g}^{-1}$ body weight $\mathrm{d}^{-1}$ ) identified by Luo \& Musick (1991) is large enough to easily account for the near doubling in egg abundance observed during the $6 \mathrm{~d}$ interval. Experimental results have also confirmed ration-related variation in batch fecundity and interspawning interval in the Japanese anchovy Engraulis japonica (Tsuruta \& Hirose 1989). Further evidence of an anchovy fecundity response to ration may exist in Brewer's (1978) observation that Engraulis mordax eggs are most abundant when the adult prey (the calanoid Acartia tonsa) is most abundant.

Adult bay anchovies appear to be adept at placing eggs in locations where salinities are consistent and copepods are abundant. Luo (1993) demonstrated that adult bay anchovies drift passively in darkness, and suggested that this behavior allows the fish to remain associated with plankton patches that were detected visually during the day. The bay anchovy spawns at night, generally between 20:00 and 24:00 h (Luo \& Musick 1991, Zastrow et al. 1991). We suggest that the adults remain spatially associated with their prey until spawning, and that their spawning intensity is influenced by previous ration. The hatching larvae are likely to be associated with elevated nauplius densities because of the inherent interdependence between copepod life stages (Table 1).

Calanoids often appeared to associate with estuarine tributary plumes (Fig. 4). As a result of municipal and agricultural development of its watersheds, Hillsborough Bay (see Fig. 1) receives a steady supply of nutrients during the dry season (Johansson 1991), and supports dense calanoid patches within its confined area (Fig. 4). Under fairly constant dry-season discharge ( $\mathrm{CV}=1.7 \%$, Table 4 values), calanoid patch formation occurred in a physiographically consistent location (Hillsborough Bay). As discharge increased and became more variable during the wet season $(\mathrm{CV}=$ $55 \%$, Table 4 values), patch formation became more spatially unpredictable and calanoids became more dispersed. Throughout these transitions, latitudinal centers of abundance for eggs and calanoids shifted together, generally remaining in the area of the 26-28 ppt isohaline (Tables 4 \& 5). In their study of the 
St. Lawrence estuary, Therriault \& Levasseur (1986) found a similar pattern for phytoplankton. Periods of low discharge were characterized by localized riverine plumes that supported high phytoplankton biomass, and periods of high discharge were characterized by phytoplankton biomass being concentrated in a more seaward location. In Tampa Bay, steady freshwater discharge during the dry season appeared to encourage aggregation of the bay anchovy's adult prey, while the more variable discharge that occurred during the wet season appeared to cause local dispersion. It is possible that calanoid aggregations formed seaward of our study area during the wet season, and that bay anchovy spawning activity was elevated there.

If the bay anchovy is an 'income breeder' (Stearns 1993), spawning soon after energy for egg production becomes available, then seasonal and spatial patterns in egg production could be largely explained by variation in metabolic rate and adult ration. This explanation differs from most temperature- and photoperiodbased explanations, which generally imply that the function of these variables is relegated to that of seasonal cues. Strong time-series correlations between egg or larval abundance and temperature, such as the one evident during the temporal survey (Table 1), are cited as support for this position. However, the spawning activity of at least 1 anchovy, Engraulis mordax, does not appear to respond to variation in photoperiod, and maximum spawning does not always occur during the warmest months or during a time of year when temperature is increasing (Leong 1971, Brewer 1978).

The bay anchovy's spawning season becomes more seasonally restricted in the northern portion of it range (Jones et al. 1978). The northern range experiences colder winters (lower adult metabolism) and is also likely to exhibit greater seasonality in plankton production (adult ration). In the Tampa Bay study area, which is nearer the southern limit of the bay anchovy's range, correlations were not only evident between temperature and density of Anchoa mitchilli larvae, but were also evident between temperature and copepod density (Table 1). Rather than being directly operational in determining spawning intensity, temperature may be indirectly operational as a measure of adult metabolic rate and the irradiance that contributes to seasonal variation in primary and secondary production. Temperature is also likely to correlate with water-mass turnovers and weather events that affect plankton aggregation. Temperature did not account for variation in egg abundance among spatial surveys (Table 5). The effect of temperature on metabolism would have been essentially constant during the spatial surveys (compared with the annual range), leaving prey availability to account for most of the variation in egg CPUE.
From a bioenergetic perspective, ration beyond that required for maintenance, activity, and somatic growth metabolism is available for egg production. The curve in Fig. 6 may represent a functional response (e.g. Rigler 1961), wherein egg production increases beyond a threshold level of prey availability, but becomes limited by handling time or maximum size-specific fecundity as prey availability continues to improve.

Close tracking of egg production on adult prey availability is only possible because the bay anchovy's interspawning interval can be short (1 to $4 \mathrm{~d}$; Luo \& Musick 1991, Zastrow et al. 1991) and because the eggs hatch quickly (<24 h; Cowan \& Houde 1990). On the other hand, Hay \& Brett (1988) found evidence that the Pacific herring Clupea harengus pallasi, an annual springtime spawner, fixes much of its size-specific fecundity at least several months before spawning, possibly during the previous summer's period of fast growth. Tsuruta \& Hirose (1989) observed an 11 to $21 \mathrm{~d}$ lag between increased ration and increased fecundity in captive Engraulis japonica. In such cases, correlations between instantaneous egg and adult prey distributions would not be expected. Whenever the interspawning interval is long, the possibility exists that the food signal is translated over an equally long period ('capital breeders'; Stearns 1993). This approach may be more conservative, providing adults with energy reserves that could be drawn upon when needed (e.g while migrating or overwintering). In planktivorous species exhibiting longer delays in their fecundity response, the larvae may be more likely to encounter insufficient prey fields. Highly variable yearly recruitment may be the result, thus explaining why capitalbreeding clupeoids tend to be longer lived than income breeders (Murphy 1968). This is opposed to the commonly held perspective (e.g. Armstrong \& Shelton 1990 ) that income breeding (high iteroparity) is compensation for low probability of batch survival in variable environments. Rather, if the income breeding closely tracks environmental variables relevant to batch survival, then the iteroparity may be seen as a seasonal fine-tuning of reproductive effort according to survival probability.

Prey patchiness has been applied to recruitment dynamics by other researchers (Lasker 1975, Peterman $\&$ Bradford 1987), yet in these cases the patchiness was proposed to influence larval survival rather than adult spawning. Regarding the critical-period-based match/ mismatch hypothesis, which holds that recruitment is partly determined by the extent of seasonal match between larval production and larval food supply, Cushing (1990, p. 263) acknowledged 'Thus, it appears that in these waters, fish - as exemplified by the anchovy, the sardine and the tuna - may well match their reproductive strategy and physiology to feeding. 
In other words, they spawn as they feed and their larvae grow in the food patches and the mismatch is minimized.' Cushing's reference to 'these waters' was to upwelling areas and oceanic divergences equatorward of $40^{\circ}$ latitude. We suggest that within-season variation in prey fields such as that induced by variability in freshwater runoff into estuaries or by variability in wind-induced upwelling in the ocean renders the income-breeding tactic more dependable than temperature or photoperiod-induced spawning seasonality. Regardless of habitat, however, fishes whose adult prey field does not correlate with that of their larvae may substitute indirect signals (i.e. temperature and photoperiod) to indicate when conditions are most salubrious for their offspring. Indirect signals are likely to be less reliable than direct signals, and may lead to greater interannual variability in recruitment success and an increase in the number of reproductive seasons required to assure replacement.

It is likely that individual fish species are situated at points along the continuum between income and capital breeding, with most sharing some characteristics of each pattern. In Tampa Bay, the short-lived, highly iteroparous bay anchovy appears to operate toward the income-spawning extreme of this continuum.

Acknowledgements. We thank S. Davis, M. Flock, T. Greely, S. Kinsey, I MacDonald, T Polliard, J. Rast and T. Sutton for assistance in the field and laboratory. J. C. Briggs, T L. Hopkins and R. R. Wilson, Jr (University of South Florida), M. S. Flannery (Southwest Florida Water Management District), R. H. McMichael, Jr, F. Kennedy (Florida Marine Research Institute), and F. Calder (Florida Department of Environmental Regulation) were instrumental in the successful completion of this project. R. R. Wilson, Jr, R. H. McMichael, Jr, and R. Muller (FMRI) reviewed the first draft of this manuscript. Funding for this research was provided by the Florida Department of Environmental Regulation, Office of Coastal. Management, using funds available through NOAA under the Coastal Zone Management Act of 1972, and by the Florida Department of Environmental Protection, using funds from. recreational saltwater fishing license fees.

\section{LITERATURE CITED}

Armstrong MJ, Shelton PA (1990) Clupeoid lufe-history styles in variable environments. Environ Biol Fish 28:77-85

Bagenal TB (1973) Fish fecundity and its relation with stock. and recruitment. Rapp Pv Réun Cons int Explor Mer 164 186-198

Bailey RS, Almatar SM (1989) Variation in the fecundity and egg weight of herring (Clupea harengus L.). Part II. Implications for hypotheses on the stability of marine fish populations. J Cons int Explor Mer 45:125-130

Brewer GD (1978) Reproduction and spawning of the northern anchovy, Engraulis mordax, in San Pedro Bay, California. Calif Fish Game 63:175-184

Castro LR, Cowen RK (1991) Environmental factors affecting the early Jje history of bay anchovy Anchoa mitchill in
Great South Bay, New York. Mar Ecol Prog Ser 76 $235-247$

Cowan JH Jr, Houde ED (1990) Growth and survival of bay anchovy Anchoa mitchilli larvae in mesocosm enclosures Mar Ecol Prog Ser 68:47-57

Cushing DH (1990) Plankton production and year-class strength in fish. populations: an update of the match/mismatch hypothesis. Adv mar Biol 26:249-293

David FN, Moore PG (1954) Notes on contaglous distributions in plant populations. Ann Bot 18:47-53

Gulland JA (1983) Fish stock assessment. John Wiley and Sons, New York

Hay DE, Brett JR (1988) Maturation and fecundity of Pacitic herring (Clupea harengus pallasi): an experimental. study with comparisons to natural populations. Can J Iish Aquat Sci 45:399-406

Houde ED (1977) Food concentration and stocking density effects on survival and growth of laboratory-reared larvae of the bay anchovy, Anchoa mitchilli and lined sole, Achirus lineatus. Mar Biol 43:333-342

Houde ED (1978) Critical food concentrations for larvae of three species of subtropical marine fishes. Bull mar Sci 28: $395-411$

Houde ED, Lovdal JA (1984) Seasonality of occurrence, foods and food preferences of ichthyoplankton in Biscayne Bay, Florida. Estuar coast Shelf Sci 18:403-419

Hunter JR (1981) Feeding ecology and predation of manne fish larvae. In: Lasker R (ed) Marine fish larvae: morphology, ecology in relation to fisheries. Washington Sea Grant Program, Univ Washington Press, Seattle, p 33-77

Hyslop EJ (1980) Stomach contents analysis - a review of methods and their application. J Fish Biol 17:411-429

Johansson JOR (1991) Long-term trends of nitrogen loading, water quality and biological indicators in Hillsborough Bay, Florida. In: Treat SF, Clark PA (eds) Proceedings, Tampa Bay area scientific information symposium 2. Tampa Bay Regional Planning Council, Tampa, p 157-176

Jones PW, Martin FD, Hardy JD Jr (1978) Development of fishes of the Mid-Atlantic Bight, Vol 1 Fish Wildl Service, US Dept Interior, p 159-163

Lasker R (1975) Field criteria for survival of anchovy larvae: the relation between inshore chlorophyll maximum layers and successful first feeding. Fish Bull US 73:453-462

Lasker R (1985) What limits clupeoid production? Can J Fish Aquat Scı 42:31-38

Leong RJH. (1971) Induced spawning of the northern anchovy Engraulis mordax. Fish Bull US 69:357-360

Lloyd M (1967) Mean crowding. J Anim Ecol 36:1-30

Luo J (1993) Tidal transport of the bay anchovy, Anchoa mitchilli, in darkness. J Fish Biol 42:531-539

Luo J, Musick JA (1991) Reproductive brology of the bay anchovy in Chesapeake Bay. Trans Am Fish Soc 120:701-710

May RC (1974) Larval mortality in marine fishes and the critcal period concept. In: Blaxter JHS (ed) The early life history of fish. Springer-Verlag, Berlin, p. 3-19

Modde T, Ross ST (1983) Trophic relationships of flshes occurring within a surf zone habitat of the northern Gulf of Mexico. Northeast Gulf Sci 6:109-120

Murphy GI (1968) Pattern in life history and the environment. Am Nat 102:391-403

Peterman RM, Bradford MJ (1987) Wind speed and mortality rate of a marine fish, the northern anchovy (Engraulis mordax). Science 235:354-356

Pielou EM (1977) Mathematical ecology. Wiley, New York

Rigler FH (1961) The relation between concentrations of food and feeding rate of Daphnia magna Siraus. Can. J Zool 39: $857-68$ 
Rothschild BJ (1986) Dynamics of marine fish populations. Harvard Univ Press, London

Rothschild BJ, Osborn TR, Dickey TD, Farmer DN1 (1989) The physical basis for recruitment variability in fish populations. J Cons int Explor Mer 45:136-145

Smith PE, Richardson S (1977) Standard techniques for pelagic fish egg and larval surveys. FAO Fish tech Pap 175

Stearns S (1993) The evolution of life histories. Oxford Univ Press, New York

Therriault JC, Levasseur M (1986) Freshwater runoff control of the spatio-temporal distribution of phytoplankton in

This article was submitted to the editor the lower St. Lawrence estuary (Canada). In: Skreslet S (ed) The role of freshwater outflow in coastal marine ecosystems. NiTO Scientific Affarrs Division, SpringerVerlag, Berlin, p 251-260

Tsuruta Y, Hirose K (1989) Internal regulation of reproduction in the Japanese anchovy (Engraulis japonica) as related to population fluctuation. Can Spec Publ Fish Aquat Sci 108: $111-119$

Zastrow CE, Houde ED, Morin LG (1991) Spawning, fecundity, hatch-date frequency and young-of-the-year growth of bay anchovy Anchoa mitchilli in mid-Chesapeake Bay. Mar Ecol Prog Ser 73:161-171

Manuscript first received: August 17, 1994 Revised version accepted: July 18, 1995 